\title{
Effect of Employee Rewards on Employee Performance at the Kenya Police Service
}

\author{
Fredrick J. Mugambi* Dr. Florence Muindi Dr. Mercy Munjuri Professor James Njihia \\ School of Business Administration, University of Nairobi, PO Box 30197 NAIROBI, 00100, G.P.O, Kenya
}

\begin{abstract}
The success and performance of any organization are determined by among others, the way the workers are remunerated and rewarded. The objective of this study was to determine the effect of employee rewards on employee performance. The study was anchored on social exchange theory. According to this theory, an employee will interact with his employer to gain a reward and the employer will interact with his employee to achieve organizational goals. The positivism approach was used to aid in hypothesis testing. The study used a crosssectional research design. Data were collected using a structured questionnaire administered to a sample size of 397 respondents drawn from the Kenya Police Service. Both descriptive and inferential statistics were used in data analysis. The study found that non-financial rewards were more valued than financial rewards. The findings revealed a significant positive relationship between employee rewards and employee performance. These findings are in line with Social Exchange Theory based on the act of reciprocity in which case the actors (employer/employee) reciprocate to each other. Reciprocity and fair exchange appear to be influential in the context of reward, work attitude, and leadership style and performance. It is therefore concluded that employee rewards influence employee performance in the Kenya Police Service, thus, Kenya Police Service should always reward employees. The study recommends that policymakers at the Kenya Police Service should embrace employee rewards. The study suggests that further research be conducted in other counties not included in this study and the results be compared for generalization purposes. It is also recommended that similar studies be conducted in the Kenya Defence Forces and private firms dealing with security issues. This will allow for the generalization of the results.
\end{abstract}

Keywords: Employee Rewards, Employee Performance at the Kenya Police Service

DOI: $10.7176 / \mathrm{EJBM} / 14-2-06$

Publication date: January $31^{\text {st }} 2022$

\section{Introduction}

The success and performance of any organization are determined by among others, the way the workers are remunerated and rewarded (Lawler, 2003). Poor incentives packages have been a major factor affecting employees' commitment and productivity (Dixit \& Bhati (2012). For any organization to achieve its objectives in any competitive society, employers must have a thorough understanding of what drives the employees to perform efficiently and reward them (Mueller, 2011). Armstrong and Baron (2006) base the whole ethos of reward and performance on the assumption that if the performance levels of employees can be raised, better organizational performance will follow as a direct result. Rewards propel and influence employee attitude in the workplace as well as stimulate the understanding between the employer and the employee.

Many factors contribute towards employees performing their jobs effectively and efficiently. Factors that are external to the worker such as the working environment, standard operating procedures, facilities and equipment required for the tasks, and the management style of the leaders influence how workers perform their jobs. Stup (2003) noted the need for the employees to have proper knowledge, skills, and right attitudes if they are to perform well in their jobs. Van der Merwe (2008) observed that there is a close association between work performance and attitude, career growth, remuneration, and non-monetary rewards such as recognition. This paper sought to answer the research question 'what is the effect of employee rewards on employee performance.

\section{Literature Review}

The paper reviewed the literature on employee rewards and employee performance. The review captured empirical reviews.

\section{Employee Rewards}

Bratton \& Gold (1999) refers to rewards as all forms of financial returns and tangible services and benefits that an employee receives as part of an employment relationship. A reward is a benefit that arises from performing a task, rendering service, or discharging a responsibility (Collins, 1995). However, Searle (1990) categorizes rewards into two broad areas, namely extrinsic rewards and intrinsic rewards. Extrinsic rewards are usually financial and include salary or pay, allowances, promotion, bonuses, and other financial benefits (Zaman, 2011). Stoner and Freeman (1992) define intrinsic rewards or non-financial rewards as the psychological reward that is experienced directly by an employee which may include but not limited to the following; recognition, appreciation and praise, 
authority and responsibility, certificate and plague, participation in decisions making, the comfort of working place, flexible working hours, social right and respect. Allen and Kilmann (2001) postulate that reward practices play a vital role in improving employee performance towards achieving organizational goals. An organization that fails to reward employees affects their performance directly (Eisenberger, et al. 2001).

\section{Employee Performance}

Employee performance has been defined as the efficiency with which jobholders perform their work that leads to institutional productivity directly or indirectly (Muchhal, 2014). Job performance can be conceptually divided into the task and contextual performance (Borman \& Motowidlo, 1993). Task performance is the effectiveness with which job incumbents perform activities that contribute to the organization's technical core (Borman \& Motowidlo, 1997). Van Scotter (2000) defines task performance as the expertise with which officeholders perform activities related to their job descriptions. It involves behaviors that are directly related to performing duties that are required by the job as defined in the job descriptions; such as job knowledge, skills, proficiency, expertise, experience, competency, and ability (Williams \& Anderson, 1991). Contextual performance is individual behaviors that contribute to the facilitation of the social and psychological context of the organization not directly related to the core task function (Borman \& Motowidlo, 1997). Organizational Citizenship Behavior is one conceptualization of contextual performance and is defined as that individual behavior that is discretionary and not directly or explicitly recognized by the formal reward system, which taken together promotes the effective functioning of the organization (Organ, 1988).

\section{Relationship between Employee Rewards and Employee Performance}

In an empirical study by Aktar et al., (2012) on the impact of rewards on employee performance in commercial banks in Bangladesh, it was established that there is a significant and positive relationship between employee rewards and employee performance. It was further revealed that though employees preferred intrinsic rewards more than extrinsic rewards both rewards contributed positively to employee performance. Kimunge (2014) conducted a study to establish whether reward, work-life balance, acquisition of skills, and career progression have a positive effect on employees resolution to stay or leave an organization at Kenya Vision 2030 Delivery Secretariat and established that reward, work-life balance, acquisition of skills and career progression had a positive effect on employees resolution to stay or leave an organization.

Sajuyigbe et al., (2013) conducted a study in some selected manufacturing companies in Nigeria and found a positive relationship between rewards and employee performance. In another study by Bari et al., (2014) on the impact of non-financial rewards on employee attitude and performance in the business institute of Karachi, it was found that non-financial rewards have a positive impact on employee attitude and performance. A study conducted by Eshak and Zakirai (2016) in the Islamic Religious Council in Kuala Lumpur, Malaysia on the relationship between reward structure and employee performance found a positive and significant relationship between intrinsic and extrinsic reward on employee performance. The findings further revealed that intrinsic reward factors have more influence on employee performance than extrinsic reward factors. This, therefore, shows that there is a strong relationship between employee reward and employee performance.

\section{Research Methodology}

The study adopted the positivism philosophy approach as the basis for testing and interpretation of the research findings. The choice of positivism was that it ensured neutrality, objectivity, clear measurement, and validity of results (Bryman \& Bell, 2008). A descriptive cross-sectional design was used as the study sought to describe and establish relationships among key study variables at a specific point in time. The target population was the police officers in the Kenya Police Service (KPS) which has a staff establishment of 42,145 officers (KPS Staff Establishment Records, 2018). This target population was spread out in the country in the forty-seven Counties. The study used multi-stage cluster sampling with the first cluster being the 47 counties in Kenya. Out of the 47 Counties, a second cluster made up of 15 counties was selected through simple random sampling. The third cluster of three police stations per county was randomly selected from each of the 15 counties. From the third cluster, a simple random sampling method was used to pick the required sample size from each of the selected police stations. The study adopted stratified random sampling and the sample size was computed by the formula proposed by Yamane (1967). The required sample size was calculated as follows

$$
\begin{aligned}
& \mathrm{n}=\mathrm{N} /\left[1+\mathrm{Ne}^{2}\right] \\
& \mathrm{n}=42,145 /\left[1+42,145^{*} 0.05^{2}\right] \\
& \mathrm{n}=397
\end{aligned}
$$

\section{Research Findings and Discussions}

The study was based on the formulated hypothesis, that was;

$\mathbf{H}_{1}$ : Employee rewards influence employee performance in the Kenya Police Service. 
The direct relationship between employee rewards and employee performance was tested using the simple linear regression method. The findings are presented in Table 1.

Table 1: Employee Rewards and Employee Performance

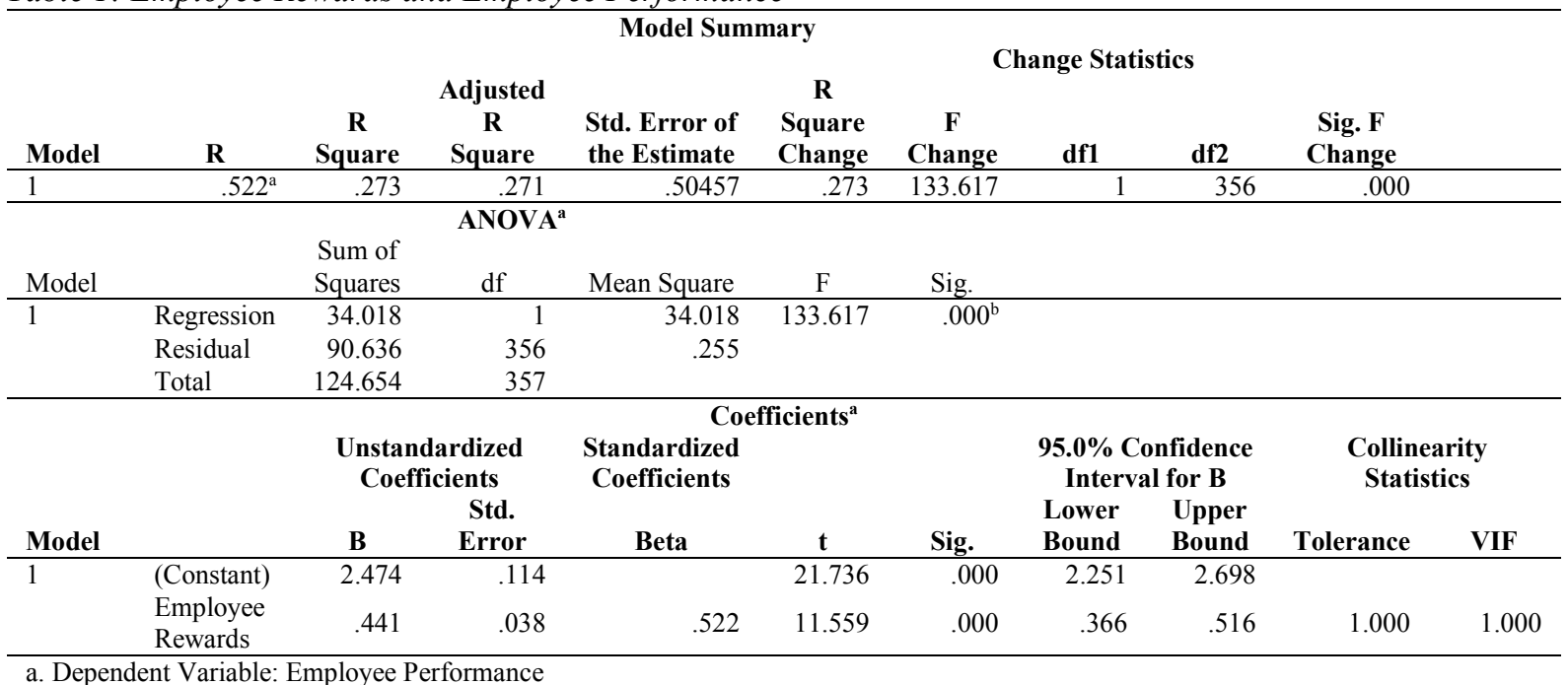

b. Predictors: (Constant), Employee Rewards

Source: Researcher, (2020).

The analysis in Table 1 indicated a moderate positive correlation between employee rewards and employee performance $(r=0.522)$. The explanatory power of the model $\left(R^{2}\right)$ equals 0.272 . This means that employee rewards account for 27.3 percent of the variation in employee performance in the Kenya Police Service. The model was overall significant $(\mathrm{F}=133.617$, $\mathrm{P}$-Value $=0.00<0.05$, individually employee rewards statistically and significantly influence employee performance $(\mathrm{t}=11.559, \mathrm{P}$-value $=0.000<0.05)$. There exists enough evidence to support the hypothesis that employee rewards influence employee performance. This is a confirmation that employee rewards influence employee performance in the Kenya Police Service. The predictive model becomes

Where:

$$
\mathrm{EP}=2.474+\text { 0.522ER }
$$

$\mathrm{EP}=$ Employee performance

$\mathrm{ER}=$ Composite index of Employee Rewards

The positive coefficient of employee rewards indicated that for every one-unit increase in employee rewards in the Kenya Police Service employee performance increases by 0.522 units holding other factors constant.

\section{Conclusion}

The study provided evidence that employee rewards significantly and statistically influence employee performance. It is therefore concluded that employee rewards influence employee performance in the Kenya Police Service, thus, Kenya Police Service should always reward employees. The findings support the Expectancy Theory, which is founded on people's expectations that they expect to be satisfied after working. The management, therefore, needs to demonstrate to the employees that their effort will be recognized and rewarded accordingly after the performance.

\section{Recommendations}

The study recommends that policymakers at the Kenya police service should embrace employee rewards. The study suggests that further research be conducted in other counties not included in this study and the results be compared for generalization purposes. It is also recommended that similar studies be conducted in the Kenya Defence Forces and private firms dealing with security issues. This will allow for the generalization of the results.

\section{References}

Allen, R.S., \& Kilmann, R.H. (2001a). The Role of the Reward System for a Total Quality Management Based Strategy, Journal of Organizational Change Management, 14 (2), 110-127

Aktar, Serena, Muhammad Kamruzzaman Sachu, Md. Emran Ali (2012) the impact of rewards on employee performance in commercial banks of Bangladesh: an empirical study IOSR Journal of Business and Management (IOSR-JBM) ISSN: 2278-487X. Volume 6, Issue 2 PP 09-15

Armstrong, M \& Baron, (2006). Human resource management practice. Kogan Page Publishers.

Bari, N; U. Arif and A. Shoailo (2014), Impact of Non-Financial Rewards on employee Attitude \& performance in the workplace. A case study of Business Institutes of Karachi 
Borman, W. C., and Motowidlo, S. J. (1993) Expanding the criterion domain to include elements of contextual performance.

Bratton, J. \& Gold, J. (1999). Human Resource Management: Theory and Practice. New York: Palgrave Macmillan Ltd.

Bryman, A. \& Bell, E. (2003). Business Research Methods. New York: Oxford University Press.

Collins Pitts, (1995). Motivating Your Organization. USA: McGraw-Hill International, 1st edition.

Dixit, V. \& Bhati, (2012). A study About Employee Commitment and its Impact on Sustained Productivity in India Auto-Component Industry. European Journal of Business and Social Sciences. Vol. 1(6), pp 44-5.

Eisenberger, R. and Rhoades, L. (2001) 'Incremental Effects Reward on Creativity', Journal of Personality and Social Psychology, Vol.81, No.4, pp.728-741.

Eshak, E.S Jamian, N.F., Jidi, M.M. \& Zakiria, N. (2016). The relationship between reward systems with employee performance. E-proceeding of the social sciences research, 103-108.

Kimunge, M.W., (2014). Effects of Total Rewards on Employee Retention; A Case Study of Kenya Vision 2030 Delivery Secretariat. Strategic Journal of Business and Change Management, 1(2), 23-29.

Lawler, E.E. (2003). Reward practices and performance management system effectiveness. Centre for effective organizations, (213), 740-9814

Muchhal, D.S. (2014) HR Practices and Job Performance. Journal of Humanities and Social Science, 19, 55-61.

Organ, D. W. (1988). Organizational citizenship behavior: The good soldier syndrome. Lexington, MA: Lexington.

Sajuyigbe, A. S., Olaoye, B. O. \& Adeyemi, M. A. (2013). Impact of Reward on Employees Performance in a Selected Manufacturing Companies in Ibadan, Oyo State, Nigeria: International Journal of Arts and Commerce. Vol.2 No.2.

Searle, P. (1990). Manage People Not Personnel, A Harvard Business review book

Stoner James A.F., R. Edward Freeman, Management (1992) New Delhi. Prentice-Hall of India

Stup, R. (2003). Control the Factors that Influence Employee Success. Managing the Hispanic Workforce Conference, Cornel University and Pennsylvania State University. [120].

The National Police Service Act (No 11A of 2011 Article 84)

Were, M. S, Gakure, R. W; Kiraithe, E. K. \& Waititu, A. G. (2013). The Influence of Resource Availability and Utilization on the Performance of the Police Force: A case study of Nairobi Police Force. Journal of Business Management and Corporate Affairs, 2(1), 1-10. [128].

Van der Merwe, I. W. (2008). “A critical Analysis of Factors that Influence Employee Work Performance". Journal of management. DO1:10.1177/01490

Van Scotter, James R. 2000. "Relationships of Task Performance and Contextual Performance with Turnover, Job Satisfaction, and Affective Commitment." Human Resource Management Review 10(1): 79-95.

Williams, L. J., \& Anderson, S. E. (1991). Job satisfaction and organizational commitment as predictors of organizational citizenship and in-role behaviors. Journal of Management, 17, 601-617.

Yamane, Taro. (1967). Statistics, An Introductory Analysis, 2nd Ed., New York: Harper and Row

Zaman, K. (2011) Relationship between Rewards and Employee Motivation in the Non-profit Organizations of Pakistan. Business Intelligence Journal, 4, 327-334. 